\title{
The Barcelona agreement: a manifesto towards the spearfishing of the future
}

\author{
Valerio Sbragaglia ${ }^{1}$, Oscar Sagué $\mathrm{Pla}^{2}$, Ana Gordoa ${ }^{3}$, Sergi Pérez Hernández ${ }^{4}$, \\ Lydia Chaparro Elias ${ }^{5}$, Mauricio Pulido ${ }^{6}$, Roberto Terol Ruiz ${ }^{2}$, Vincent Giroud ${ }^{7}$ \\ ${ }^{1}$ Department of Marine Renewable Resources, Institut de Ciències del Mar, CSIC, Barcelona, Spain. \\ E-mail: valeriosbra@gmail.com \\ ${ }^{2}$ International Forum for Sustainable Underwater Activities (IFSUA), Barcelona, Spain. \\ ${ }^{3}$ Department of Marine Ecology, Centro de Estudios Avanzados de Blanes, CSIC, Blanes, Girona, Spain. \\ ${ }^{4}$ Spanish Federation of Underwater Activities (FEDAS), Barcelona, Spain. \\ ${ }^{5}$ Fundation ENT, Vilanova i la Geltrú, Barcelona, Spain. \\ ${ }^{6}$ Mediterranean Platform of Artisanal Fishers (MEDARTNET). \\ ${ }^{7}$ Spearfishing Association of Barcelona (APS), Barcelona, Spain.
}

\begin{abstract}
Summary: The Spearfishing Association of Barcelona (APS) recently celebrated its $70^{\text {th }}$ anniversary and decided to write a manifesto called: "The Barcelona Agreement: A Manifesto Towards the Spearfishing of the Future". The Manifesto was discussed and approved during a round table at the Maritime Museum of Barcelona on 27 February 2016, in which delegates of several stakeholders took part. The Agreement is a revision of the most important points that the authors consider to be fundamental for a sustainable development of spearfishing in the future. The authors expect that this manifesto will be a starting point for a constructive discussion to increase knowledge, efficient practice and effective management of spearfishing.
\end{abstract}

Keywords: spearfishing; sustainable; regulation; impact.

La carta de Barcelona: hacia una pesca submarina del futuro

Resumen: En motivo de la celebración de su 70 aniversario, la Asociación de Pesca Submarina de Barcelona (APS) decidió escribir un manifiesto llamado: "La carta de Barcelona: un manifiesto hacia la pesca submarina del futuro". El contenido fue discutido y aprobado el 27 de febrero de 2016 durante una mesa redonda organizada en el Museo Marítimo de Barcelona y en la que participaron delegados de distintos grupos de interés. El manifiesto es una revisión de los puntos que, según los autores, son fundamentales por un desarrollo sostenible de la pesca submarina en el futuro. Finalmente, los autores pretenden que este manifiesto sea un punto de partida para una discusión constructiva sobre el conocimiento, la práctica eficiente y la gestión efectiva de la pesca submarina.

Palabras clave: pesca submarina; sostenibilidad; regulación; impacto.

Citation/Como citar este artículo: Sbragaglia V., Sagué Pla O., Gordoa A., Pérez Hernández S., Chaparro Elias L., Pulido M., Terol Ruiz R., Giroud V. 2016. The Barcelona agreement: a manifesto towards the spearfishing of the future. Sci. Mar. 80(3): 423-426. doi: http://dx.doi.org/10.3989/scimar.04504.01A

Editor: D. Vaqué.

Received: July 7, 2016. Accepted: July 19, 2016. Published: September 30, 2016.

Copyright: (C) 2016 CSIC. This is an open-access article distributed under the terms of the Creative Commons Attribution (CC-by) Spain 3.0 License.

\section{PREFACE}

On February 2016 the Spearfishing Association of Barcelona (APS) celebrated its $70^{\text {th }}$ anniversary in the splendid setting of the Maritime Museum of Barcelona. The APS was created in 1946 (Fig. 1) and is the oldest association of recreational underwater activities in Spain and one of the older in the world.
The APS has always pioneered the sector of underwater activities and during its $70^{\text {th }}$ anniversary it decided that the time had come to once more drive the spearfishing sector towards the new challenges of the future by writing a straightforward manifesto called "The Barcelona Agreement: A Manifesto Towards the Spearfishing of the Future". The Manifesto was presented and discussed during a round table at the Maritime Museum 


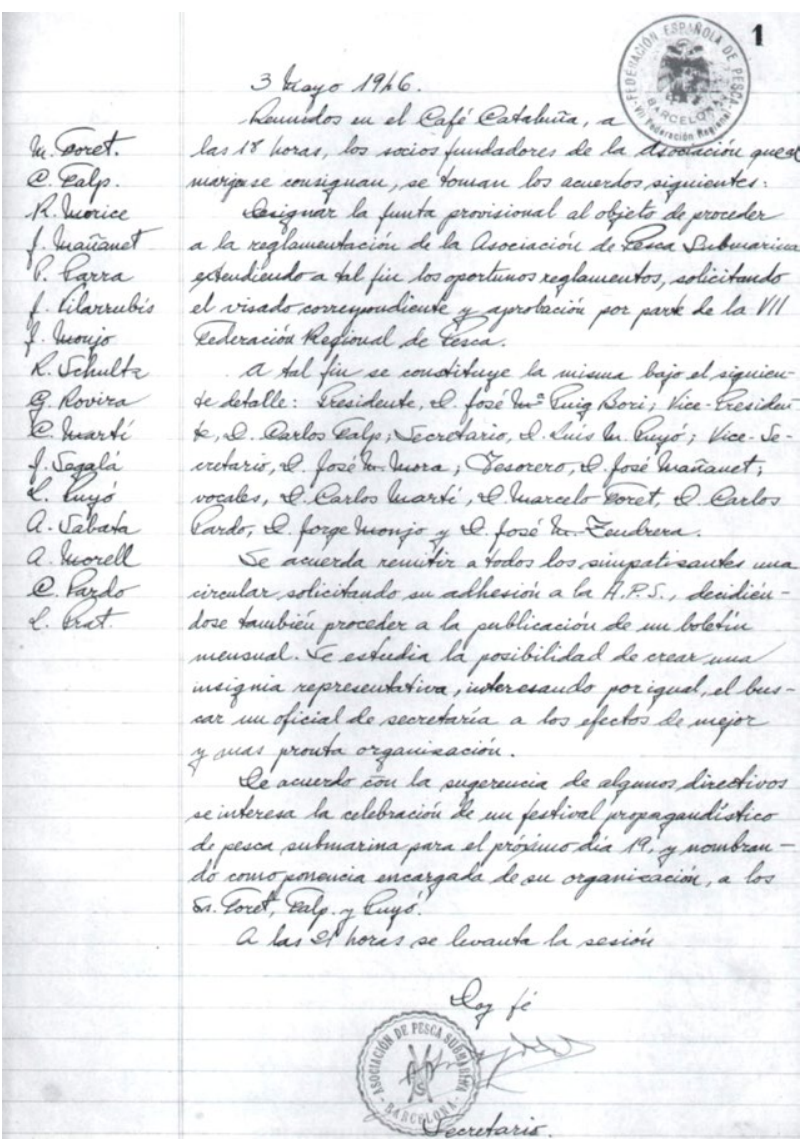

Fig. 1 - Deed of Constitution of the Spearfishing Association of Barcelona (3 May 1946).

of Barcelona on 27 February 2016 (Fig. 2). The members of the round table were spearfishing stakeholders, managers and other groups of interest (small-scale commercial fisheries, underwater activities, environmental NGOs and researchers in marine science).

\section{THE BARCELONA AGREEMENT: A MANIFESTO TOWARDS THE SPEARFISHING OF THE FUTURE}

\section{Introduction}

Spearfishing is an underwater fishing practised in Spain and many other countries using free-diving techniques for both recreation and sport. When in 1946 a group of spearfishing enthusiasts founded the Spearfishing Association of Barcelona (APS), those few people who dared to dive at sea were considered heroes. Marine coastal ecosystems were exploited little and no clear distinction had been made between commercial and recreational fisheries. Marine research and management were in their initial stages.

From the early $20^{\text {th }}$ century until now the European population has almost doubled, and coastal zones have become popular as permanent or seasonal residences. Consequently, pressure on those areas and on marine renewable resources has increased from both commercial fisheries and the increasingly popular recreational fisheries.
The most recent scientific reports state that at about $90 \%-95 \%$ of the Mediterranean species under study are overexploited. Furthermore, only a few of the species exploited by fisheries and for recreation are under evaluation and/or properly managed.

Thanks to technological development, the techniques and equipment used by all fishing sectors have progressed. Once practised by few with rudimentary tools and equipment, spearfishing in inshore waters is now a relatively common activity. It has at times been considered the main threat to coastal fish stocks and it is often the only fishing activity that is prohibited in marine protected areas.

Does spearfishing have a place as a future maritime recreational activity? Does it need to be reviewed? What are the challenges to be faced? Does it provide any benefits to society?

\section{Impacts}

Like other maritime harvesting activities, spearfishing obviously has an impact on the exploited species. The impact can vary greatly depending on many variables (e.g. specific local regulations, individual ethics, ecology of the target species, time of year and depth). In order to properly assess it, the relative contributions of other harvesting activities must always be taken into account. It is broadly recognized and accepted by the scientific community that overfishing (in all its dimensions) has the biggest impact on the marine resources. Other factors are the habitat degradation, pollution, decrease in river flow, anthropization of the coastline, arrival of tropical species and climate change, to name but a few.

It is therefore obvious that the impact of spearfishing will depend on the relative impact of other activities and on the selectivity of spearfishing itself, which is not always a synonymous of sustainability. Selectivity applied with the wrong criteria can be the worst enemy of spearfishing, but if applied with integrity it can be its strongest ally. Managers must understand that selectivity of spearfishing (the highest among all the fishing techniques) allows a wide range of management actions that, if applied properly, can guarantee a high level of sustainability.

Finally, to ensure a sustainable future for spearfishing, managers should understand that several parties have a role to play. Scientists must assess the impact of fishing activities, local governments must support their research with appropriate funding, and stakeholders must cooperate actively and help to achieve the best results.

\section{Challenges}

Management of maritime activities has sometimes been influenced by political interests. Therefore, scientific knowledge is not always the driving force of management measures and current knowledge is not always integrated into management plans.

Spearfishing has generally been regulated without a solid and updated knowledge of the activity. As 


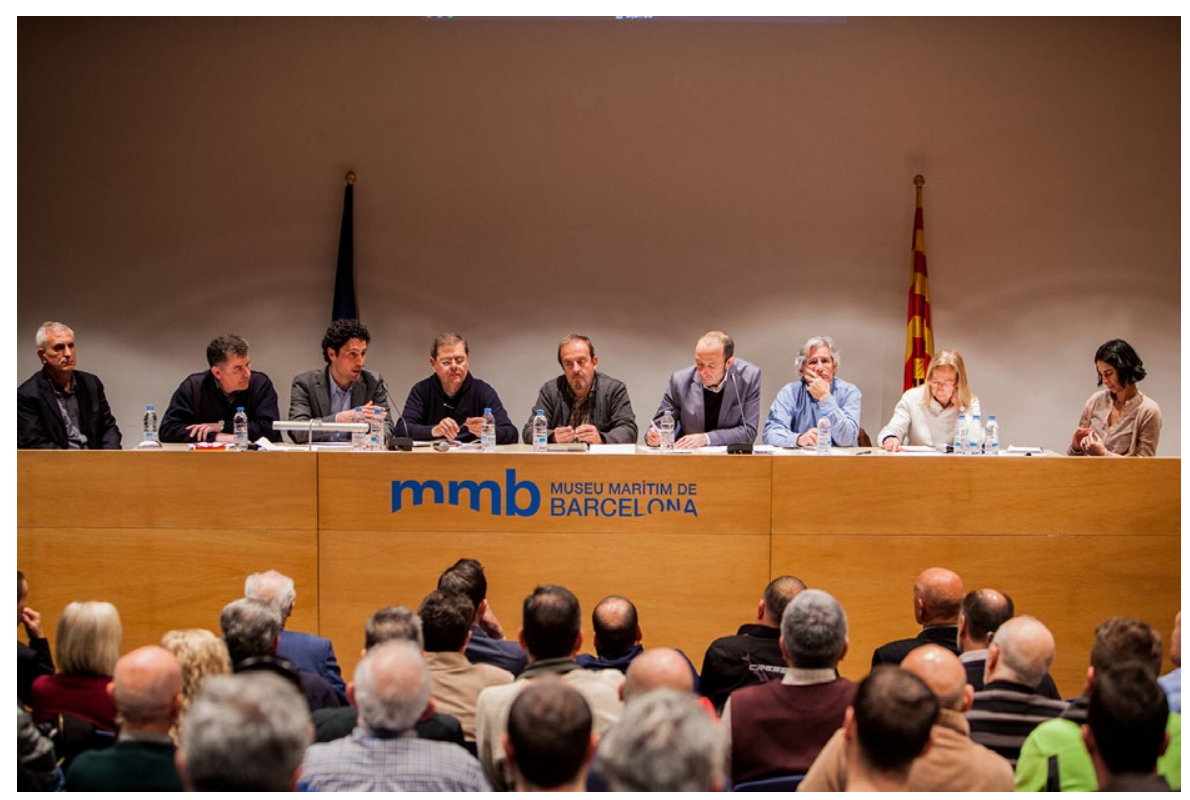

Fig. 2 - Discussion and approval of the Barcelona Agreement at the Maritime Museum of Barcelona.

spearfishers are a small group, they have often been discriminated in favour of top-down management policies. Therefore, in order to achieve healthy coastal ecosystems and fisheries, it is essential that managers develop cross-cutting policies with the active participation of all stakeholders, including small groups such as spearfishers.

The representatives of spearfishers must develop, disseminate and promote, together with researchers, guidelines of good practices that should form the basis for an ethical code of spearfishing. The spearfishing industry, retailers, harbours and marinas must help disseminate the guidelines. Finally, we strongly believe that a key concept for the spearfishing of the future is "self-regulation".

Self-regulation means that spearfishers must analyse their actions in accordance with their perception of the marine environment. Spearfishing needs to find a new identity capable of adapting to present and future challenges, which will only be possible if spearfishers recognize their specific impact and voluntarily apply a self-regulation.

The new identity must anticipate new laws and regulations and open the doors towards a future in which only responsible fishing can survive. As key drivers of social cohesion among fishers, associations have a significant role to play and they can be the catalyst for achieving the new identity, through education, dissemination and promotion programmes. Below are some examples for further development in the process of self-regulation:

\section{Temporal self-regulation}

Though underwater activities make them feel better, spearfishers must realize that they are not welcome under the sea. Human beings (with spearguns, scuba or snorkels) do not belong to the underwater ecosystem and must limit the time they spend underwater.

\section{Spatial self-regulation}

The time spent in the same area must also be limited. When the same places are frequented and exploited, they become more susceptible to suffering impacts.

\section{Seasonal self-regulation}

Fish behaviour varies throughout the year, in particular for reproductive reasons. During the spawning season many species are more vulnerable. Spearfishers can voluntarily apply a self-regulation even if there are no specific regulations.

\section{Quantitative self-regulation}

Captures must be limited according to food needs. There are limits imposed by the law, and days on which these limits are reached are rare, but spearfishers can decide to stop before reaching them.

\section{Representation}

Spearfishing is not an isolated activity but one of the several activities carried out in coastal ecosystems, usually exploiting the common resources used by small-scale commercial fisheries and other recreational fisheries. Spearfishers must therefore be recognized as legitimate stakeholders in maritime and fishing activities and must be held at the same level as the other stakeholders when it comes to designing and discussing management plans.

\section{Spearfishing and scientific research}

Spearfishing is an activity of search and exploration. This gives it a unique added value compared with other activities carried out in the coastal zone. Spearfishers are undoubtedly the group who spend most time under 
water gathering direct observations. Their great knowledge of coastal ecosystems can be extremely important for scientific research. Bridges between spearfishers and scientists must be created to encourage the transfer of knowledge between the two groups. In fact, science can benefit from additional data thanks to spearfishing activities and spearfishing can better understand the dynamics of coastal ecosystems thanks to science. However, there is an alarming lack of knowledge about spearfishing, recreational fishery, and coastal ecosystems in general. Managers must significantly increase funding to increase this knowledge, while spearfishers must vigorously collaborate to accelerate the process.

\section{Economy and sociology of spearfishing}

As well as industrial fisheries, there is also a spearfishing industry and a commercial network. They have the same right to make their livelihood from marine resources as commercial fisheries have. This important issue must be recognized and it should stimulate managers to find the most appropriate solutions to guarantee the highest level of sustainability for all stakeholders.

Spearfishing associations generate an essential social benefit, as they are an example of integration of different social strata and different nationalities. Furthermore, spearfishing can increase self-consciousness and self-control with all the associated benefits.

\section{Poaching}

Poaching is not directly associated with spearfishing, but unfortunately it exists in all activities that exploit marine resources. Managers and stakeholders' representatives must fight poaching, increase control and seek alliances between them.

\section{Spearfishing competitions}

Spearfishing competitions have often been criticized. Scientific research, with the help of managers, should evaluate their feasibility and, if possible, seek alternatives that will allow their positive aspects to be maintained.

\section{Epilogue}

This agreement is not intended to be a detailed analysis of the problems associated with spearfishing and of the possible solutions, but a starting point for a constructive discussion to increase knowledge, efficient practice and effective management of the activity.

\section{ACKNOWLEDGEMENTS}

We would like to thank the General Office of Fishery and Maritime Affairs of Catalonia, the Maritime Museum of Barcelona, CRESSI and BEUCHAT for their strong support during the activities associated with this manifesto. We are also grateful to the threetimes spearfishing world champions Josep Amengual (1973-1981-1985), Renzo Mazzarri (1987-1989-1992) and Pedro Carbonell (1996-2000-2002) for their valuable contributions and suggestions during the discussion and approval of this manifesto. 